\title{
Why Are Multinational Sales Declining in Pakistan? Evidence from the Tobacco Industry
}

\author{
Aliya Bushra* and Nasra Wajiha**
}

\begin{abstract}
Pakistan's multinational companies have strong potential for growth and represent a large and increasing number of consumers. Unfortunately, their sales have been affected by certain factors. This study identifies these factors using a mixed-methods approach and qualitative data collected through semi-structured interviews and focus groups. We administered 100 questionnaires among the employees of two large tobacco manufacturers. The results indicate that brand switching, product development, product mix, point of sale, competition, and price are significant factors that affect sales in the tobacco industry.
\end{abstract}

Keywords: Mixed methods, profitability, brand switching, product mix, point of sale, promotion.

JEL classification: L10, L11, L19.

\section{Introduction}

The act of exchanging a product or service for money, i.e., completing a commercial activity, is known as a sale. A company's foremost purpose is to earn revenue or profit in order to survive in a dynamic market and under intense competition. Companies' sales depend on their customers' perception and level of satisfaction after purchasing a product. A company that provides better value to its customers will generate more revenue, and increase customer satisfaction and brand loyalty. Sales are a motivating factor for firms and a decline in sales will eventually affect company morale.

This study investigates why the sales of multinational firms are declining so rapidly in Pakistan, and uses the tobacco industry as a unit of analysis. The tobacco industry has strong potential for future growth and

\footnotetext{
* The author is a senior teaching fellow at the Department of Business Administration, Lahore School of Economics.

** The author is head of the Department of Psychology at the Government College for Women in Lahore.
} 
caters to a large and increasing number of consumers. However, in Pakistan's case, the industry has witnessed decreasing sales in the last couple of years.

We have collected data for this study using a mixed-methods approach. Semi-structured interviews were conducted with a sample of employees at the Pakistan Tobacco Company (PTC) and Philip Morris (Pakistan) (PMP) Limited (formerly known as Lakson Tobacco Limited) two of the largest cigarette manufacturers in the domestic market. We asked them to identify which factors they thought had affected their sales and what explained the rapid decrease in profitability. A focus group discussion was also conducted to collect information from customers concerning their brand preferences and purchasing decisions.

A quantitative survey was conducted to empirically test the reasons for the decrease in sales. Our research objectives are, therefore, to determine the reasons for the decline in sales and to observe which factors affect sales with a view to recommending policy measures.

\section{Literature Review}

Donovan, Jancey, and Jones (2002) investigate point-of-sale (POS) advertisement, brand user image, and its impact on the sales of cigarettes. They find that tobacco POS advertisement increases and facilitates brand imagery. The study's results are based on a questionnaire that was distributed (with the permission of the authorities) among a sample of 100 students from four western Australian schools. The students were divided into groups and asked to identify different brands (such as Nike, Coke, Cadbury, McDonalds, Benson \& Hedges, and Marlboro) based on the brand name and, in a few cases, on pack and poster advertisements. They were found to be fully aware of the different brand names, especially for brands such as Nike and Cadbury that they routinely encountered. However, 88 percent were also well aware of the cigarette brand names.

Participants described Benson \& Hedges (based on the advertisement) as interesting, "cool," "relaxed," and "classy." They appeared to be less impressed with Marlboro due to its outdoors image and element of adventure, perceiving it as "relaxed," "adventurous," and "out of date." The Tobacco Control Department reports that 20,000 youth take up smoking every year and 90 percent start before the age of 18 . Although the advertisement of cigarettes is banned in many countries, Donovan et al. (2002) show that students easily recognize brand names and 
product categories. Their brand awareness and self-identification gives tobacco companies the chance to quantify the effectiveness of POS advertisement in the form of brand imagery.

Katz and Lavack (2002) find that promotion in selected areas (bars, clubs) or at specific events gives tobacco companies a better chance to create and reinforce their brand image by targeting the desired market segment, providing brand trials and samples through promotional programs, and by using environmental and social influences to augment sales. The authors review more than 2,000 tobacco industry documents and interview a sample of bar managers in the US and overseas. Their model measures how the strategies above are carried out, the number of people exposed to them, and the impact of promotional items on product sales. The latter activity encourages word-of-mouth advertisement messages with strong consequences in terms of brand image and a long-term effect on people's environmental, social, and lifestyle elements.

DiFranza, Eddy, Brown, Ryan, and Bogojavlensky (2001) investigate the development of brand selection and consequent brand loyalty among youth. A sample of 721 individuals was asked about their past and current experience with cigarettes. The interviews were conducted in the form of consumer intercept marketing surveys at shopping malls, parks, and beaches. Respondents were asked which key elements made a particular brand their favorite and how they had selected that brand initially.

The study's results show that 69 percent said their friends and siblings had prompted them to smoke for the first time; 50 percent said they had subsequently smoked up to three cigarettes per day; and 67 percent had continued to purchase the same brand. Their favorite brand tended to be the brand they routinely purchased or had last purchased. Brand loyalty is thus associated with the initial brand purchased, which gives that particular cigarette company an advantage that can be augmented through print advertising, free samples, package design, and the appeal to health through low-tar cigarettes.

Randall, Ulrich, and Reibstein (1998) look at how product quality varies with brand equity. Based on a sample of 100 respondents, they find that high-quality and premium products have better brand equity than lowquality products. When the quality of similar products deviates, marketers refer to this as vertical differentiation. A deviation within the category of the product is called horizontal differentiation. The authors test whether high- 
quality products are associated with greater brand equity or if there is a negative relation with low-quality product line. The results suggest that product quality is essential to creating brand equity and enhancing sales. Customer satisfaction and desired value are key to brand equity.

Polo, Sese, and Verhoef (2011) analyze customer retention and brand memorization, based on a longitudinal study of 650 consumers. Customer retention is an important part of brand equity and marketing mix. The study tests the relation between brand retention and its effect on sales. Brand retention is defined as the brand image with which customers can easily identify, and is an effective tool for brand recognition and recall. The results suggest that the higher the retention, the stronger will be the brand recognition. Moreover, brand retention by customers and different marketing efforts are not static. The study emphasizes pre- and postpurchase decisions in examining the effect of pricing, quality, image, recall, and mass advertising on overall sales through brand retention.

Gómez, McLaughlin, and Wittink (2004) find a positive relationship between customer satisfaction and the sales of a brand product. The results of their empirical study imply that dissatisfied consumers will eventually develop a negative perception of the brand product, causing sales to decline. Creating and retaining customer loyalty is, therefore, the foremost element in business operations. This makes it important to analyze the factors that determine customer satisfaction and retention, and the consequent advantages for firms who do so.

Honjo and Kawachi (2000) discuss the government's role in the tobacco industry and its effect on smoking rates, industry practices, and tobacco sales in the Japanese market. Based on a literature review for the period 1980-96, the authors find that there was significant use of cigarettes when Japan opened its market to overseas cigarette companies. Aggressive promotional marketing both by US and Japanese tobacco companies has led to higher sales. This implies that, if the government were to control illicit sales of tobacco and allow companies to work within certain limitations, then the industry would be able to contribute substantially to tax revenues.

Danneels (2002) examines the relation between product innovation and firm competence. Product innovation is linked to competence in technologies and customer demand, and can lead to firm renewal. Based on a sample of five high-technology firms (including interviews, observations, and company documents), the study suggests that product innovation based on customer and technological demands can help firms compete, survive, and prosper in a dynamic market. 
Hudmon et al. (2006) gauge the effect of tobacco market penetration and development on sales. Their sample comprises 1,168 licensed stores (gas stations, large retail stores, pharmacies), 1,518 students, and 988 adult chain smokers. Their analysis of the data collected on cigarette sales indicates that tapping untouched market segments will eventually increase sales. Most smokers said that, when cigarettes were available in areas they visited frequently or by chance, they were likely to consume more. This makes it a useful tactic to ensure customer retention, while posters displayed at sales counters increase brand awareness among youth.

Reed, Anderson, and Burns (2006) find that the launch and advertisement of low-tar cigarettes has increased sales. Their study is based on 20 low-tar brands launched between 1960 and 1996. The authors review brand advertisements and sales, and conclude that increased awareness of low-tar cigarettes as a healthier alternative boosts sales among consumers who had decided to quit.

\section{Methodology}

Our qualitative data was collected through semi-structured interviews with employees of PTC and PMP, and with a focus group of consumers. Questionnaires were administered to a total sample of 100 respondents (50 employees and 50 consumers) to collect empirical data.

\subsection{Sample Criteria and Instrument}

The final sample of 100 employees was based on the following criteria: gender (male or female), age (18 to 60 years), level of education (the minimum being intermediate level), and designation (manager, assistant manager, department or division head, sales field leader, supervisor, retailer, customer).

We used a structured questionnaire drawn from Randall et al. (1998) with some modifications. The instrument included 16 questions in all, of which 12 measured the main dependent variable (decline in sales). The remaining questions were on demographic variables. All the questions were close-ended and based on the Likert five-point scale (from $1=$ strongly disagree to $5=$ strongly agree). The questionnaire consisted of two sections: (i) decline in sales (dependent variable) and (ii) POS, promotion, product mix, market development, product development, brand switching, social marketing, government regulation, competition, and brand loyalty (independent variables) (see Appendix). 


\subsection{Theoretical Framework and Variables}

The variables we have used are described below. Figure 1 illustrates the theoretical framework.

- POS advertisement or brand image refers to the image the brand portrays and defines the characteristics associated with it. POS advertisement is important because consumers are exposed to it at the point they purchase the product.

- Promotions are used to promote sales, and include different techniques such as samples and games. They are used to enhance product/consumer demand and to stimulate market demand or improve product availability.

- Shelf space is the space provided by a retailer and is the last point at which the consumer is exposed to the product before purchase.

- Quality refers to the quality of the product, including packaging.

- Customer preference indicates the choice of a brand relative to its competitors.

- Competition refers to the presence of substitutes and other brands of the same product. Competition is influenced by market structure.

- Customer retention reflects recurring customers and the firm's ability to maintain a long-term relationship with them. Firms take various steps toward customer retention such as building a strong relationship on the basis of trust, etc.

\section{Figure 1: Theoretical framework}

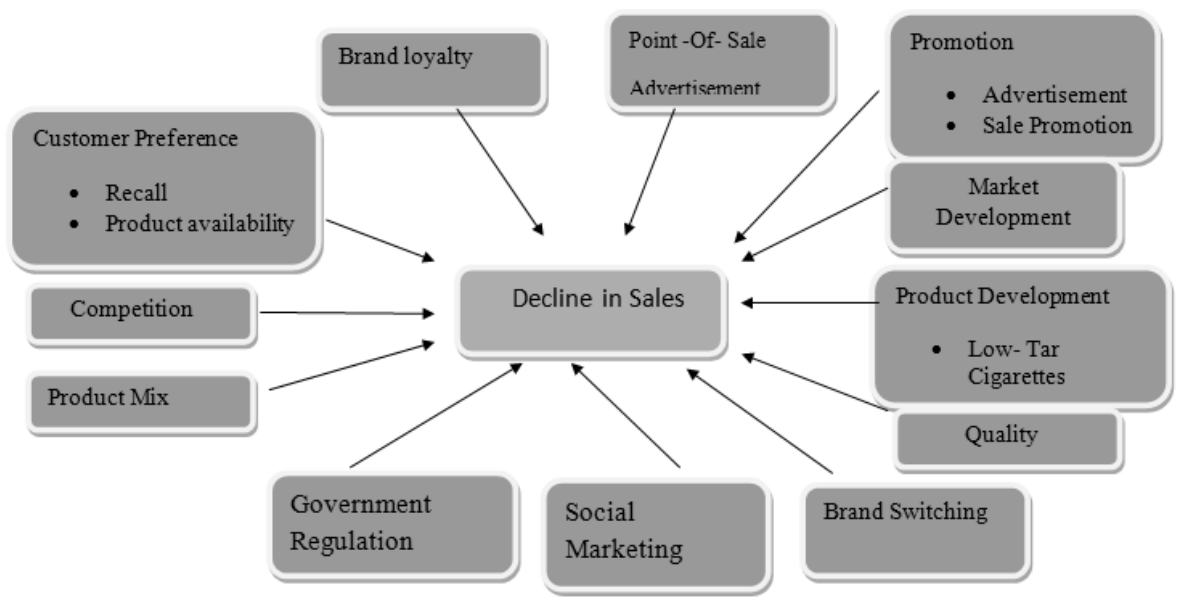


- Customer satisfaction refers to the utility a customer gains from his or her consumption of the product. A customer is deemed "satisfied" if the product delivers the utility he or she expects.

- Government regulation refers to the policies regarding business operations such as taxes and the laws a company has to follow to do business in the country.

- Product mix refers to the bundle of products a company produces to help it generate more profit.

- Social marketing and online advertisement refers to the use of the Internet and other social interaction sites to endorse a product and create a market among consumers.

- Product quality indicates the characteristics of a product that contribute to its ability to meet the given requirements.

- Product innovation refers to the addition of new features to a product or the creation of a new product in the market.

\subsection{Research Hypotheses}

Our hypotheses are as follows:

- H1: There is a negative relationship between pricing and sales decline.

- H2: There is a positive relationship between brand switching and sales decline.

- H3: There is a negative relationship between POS advertisement and sales decline.

- H4: There is a negative relationship between promotion and sales decline.

- H5: There is a negative relationship between product mix and sales decline.

- H6: There is a positive relationship between quality and sales decline.

- H7: There is a negative relationship between customer preference and sales decline.

- H8: There is a positive relationship between competition and sales decline.

- H9: There is a negative relationship between product development and sales decline. 
- H10: There is a negative relationship between government regulation and sales decline.

- H11: There is a negative relationship between market development and sales decline.

- H12: There is a negative relationship between social marketing and sales decline.

\subsection{Regression Model}

The model we employ is given below:

$$
\begin{aligned}
S_{t}= & a_{0}+b_{1 t} B S_{t}+b_{2 t} P O S_{t}+b_{3 t} P_{t}+b_{4 t} Q_{t}+b_{5 t} C_{t}+b_{6 t} C P_{t}+b_{7 t} G R_{t}+b_{8 t} P D_{t} \\
& +b_{9 t} M D_{t}+b_{10 t} S M_{t}+b_{11 t} P M_{t}+b_{12 t} P R_{t}+\varepsilon
\end{aligned}
$$

where $\mathrm{S}$ is the dependent variable, i.e., sales, BS is brand switching, POS is POS advertisement, $\mathrm{P}$ is pricing, $\mathrm{Q}$ is quality, $\mathrm{C}$ is competition, $\mathrm{CP}$ is customer preference, GR is government regulation, $\mathrm{PD}$ is product development, MD is market development, SM is social marketing, PM is product mix, PR is promotions, $\varepsilon$ is the error term, $a_{0}$ is a constant, $t$ is the current time period, and $\beta$ is a coefficient.

\section{Results}

\subsection{Results of Qualitative Research}

The focus group comprised smokers under the age of 30, who were selected as being the customers on which tobacco companies focus most. Their feedback revealed that they had always smoked the same brand (since they started smoking) because it was affordable and easily available. Most respondents came from a rural background and said they had started smoking as a result of peer pressure. They also thought that aggressive marketing, low pricing, and improved product quality led to increased sales. When asked to comment on the absence of the product in most urban areas, respondents said that it created a false customer perception about the quality of the product.

The semi-structured interviews were conducted with PTC and PMP employees. Noveen Akhtar, a senior trade marketing officer at PTC, was asked why PTC brands were seen as superior to PMP brands. He said that brand loyalty mattered the most in creating value for customers. Aggressive marketing also influenced their decisions. Giving the example of the brand Capstan, he said that PTC had halved the price and re- 
launched the brand aggressively. Since then, Capstan sales had soared. As a product of Pall Mall, a renowned brand, people had liked its quality but found the price too high. The CEO had then decided to reduce the price by half. Capstan had taken the lead to the extent that it had even affected other PTC brands. A disadvantage of reducing the price, however, was that people usually perceived low-priced products as inferior in quality.

Usama Sher, a sales manger at PMP, said that new smokers usually started smoking as an experiment, influenced by friends or seeing their peers smoke a certain brand. Most youth smoked premium brands such as Dunhill, Benson, Marlboro, or other imported brands because they felt these products were better than medium Pakistani brands. Since the introduction of pictorial health warnings, an interesting observation was that people had started to give up brands such as Embassy, Morven, and K-2 and had moved to premium or more expensive brands that they perceived as being less damaging than cheaper products.

Bilal Ahmad, a senior trade marketing officer at PMP, said that if a company was unable to provide unique attributes to a product, it would fail to capture the market. Perception, quality, and target markets had remained almost the same for such brands. People were attracted to new flavors and so companies needed to provide variety or put forward unique selling propositions to customers.

\subsection{Empirical Results of Quantitative Data}

We estimate the model below as follows:

$$
\begin{aligned}
S_{t}= & 0.220973+0.328446 * B S+0.118844 * P O S+0.103101 * P+0.035559 \\
& * Q+0.097060 * C-0.012802 * C P-0.011788 * G R+0.158107 * P D- \\
& 0.018275 * M D+0.004015 * S M+0.160249 * P M-0.019661 * P
\end{aligned}
$$

The analysis below is informed by the results obtained from the linear regression model above: of the 12 variables, six are significant (see Table 1). 
Table 1: Results of regression model

\begin{tabular}{lccl}
\hline Variable & Standardized coefficient & $\mathbf{t}$ & P-value \\
\hline (Constant) & & 1.853 & 0.067 \\
Brand switching & 0.323 & 5.346 & $0.000^{* * *}$ \\
POS advertisement & 0.126 & 2.629 & $0.010^{* * *}$ \\
Price & 0.123 & 2.859 & $0.005^{* * *}$ \\
Quality & 0.043 & 1.589 & 0.116 \\
Competition & 0.121 & 4.287 & $0.000^{* * *}$ \\
Customer preference & -0.016 & -0.747 & 0.457 \\
Government regulation & -0.014 & -0.660 & 0.511 \\
Product development & 0.168 & 4.117 & $0.000^{* * *}$ \\
Market development & -0.029 & -1.547 & 0.125 \\
Social marketing & 0.005 & 0.268 & 0.789 \\
Product mix & 0.169 & 4.550 & $0.000^{* * *}$ \\
Promotion & -0.027 & -1.467 & 0.146 \\
\hline
\end{tabular}

Note: ${ }^{* * *}=$ significant at $99 \%$.

Source: Authors' calculations.

BS has a positive p-value of 0.0000 , indicating a positive and highly significant relationship with $\mathrm{S}$. This implies that brand switching has a strong, directly proportional impact on sales decline. Customers who change their brand present an opportunity for its competitors. Aggressive marketing in the form of reduced prices, enhanced quality, or a change in customer preferences may compel consumers to switch brands even if most prefer to remain loyal to their initial brand. Companies can protect their customer market through product innovations and by enhancing quality.

POS has a positive p-value of 0.01 , indicating a positive and highly significant relationship with $\mathrm{S}$. POS advertisement plays a vital role in sales because it creates a brand image during the consumer's purchase decision and creates further public awareness of the product. However, advertisement of cigarettes is banned in many countries (including Pakistan) and people often ignore advertisements displayed in shops. The restriction on POS advertisement prevents companies from using attractive messages to draw customers.

Although consumer awareness of brand names and product categories is usually passed on easily to customers through POS advertisement, we find that POS has a highly significant and positive 
impact on sales decline as a result of excessive advertisement and the emphasis on a negative health image. Brand selection is also affected by word-of-mouth advertisement and peer influence, in turn affecting sales.

$\mathrm{P}$ has a positive $\mathrm{p}$-value of 0.0053 , which points to a positive and highly significant relationship with $\mathrm{S}$. This implies that customers are influenced by pricing, given that inflation/recession decreases their purchasing power. Pricing usually attracts customers and, in some cases, retains loyal customers. In Pakistan's context, the current price war in the domestic tobacco market accounts for the decline in sales.

$\mathrm{C}$ has a positive p-vale of 0.0000 , indicating a positive and highly significant relationship with $\mathrm{S}$. Competition within the industry affects the sales of cigarettes and firm performance because it influences customer loyalty through price wars. It also brings in innovation and new products, making it difficult for some companies to survive: the first mover has the advantage. Competition is directly proportional to sales decline due to price wars.

PD has a positive p-value of 0.0001 , which shows a positive and highly significant relationship with $\mathrm{S}$. Over time, customer preferences, tastes, expectations, and demand change, compelling companies to develop their products further. Consumers demand value for money and new product features, which suggests that product development is essential to creating brand equity and enhancing sales. For instance, the launch of low-tar cigarettes is likely to create consumer hype while failure to do so may cause a decline in sales. Product development is, therefore, directly proportional to sales.

PM has a positive $\mathrm{p}$-value of 0.0000 , indicating a positive and highly significant relationship with $\mathrm{S}$. Packaging and size tend to attract customers and increase sales. Improvements in product mix attract new customers while maintaining the loyalty of existing customers, who are likely to value the change, given their long use of the product. Thus, a low product mix is directly proportional to sales decline.

The independent variables that are insignificant are: quality, customer preferences, government regulation, market development, social marketing, and promotion. The value of the adjusted R-squared term is 0.970921 (Table 2), which implies that 97 percent of the dependent variable is explained by the independent variables. 
Table 2: ANOVA results

\begin{tabular}{lccccc}
\hline Model & Sum of squares & df & Mean square & F & Sig. \\
\hline Regression & 21.204 & 12 & 1.767 & 276.457 & 0.000 \\
Residual & 0.556 & 87 & 0.006 & & \\
Total & 21.760 & 99 & & & \\
\hline
\end{tabular}

Source: Authors' calculations.

\section{Discussion}

We find that brand switching has a positive and highly significant impact on sales; this result is in line with Sun, Neslin, and Srinivasan (2003). POS advertisement is also positive and highly significant, although Donovan et al. (2002) find that it has a negative relationship with sales decline. This difference may be because some companies are unable to use POS advertising (although it is an effective means even when restricted). It is possible that competitors employ this method for medium-range products in major shops. This implies that firms should focus on aggressively advertising their premium brands. The intensive use of this means of advertising by the beverages industry, for example, coupled with restrictions imposed by the government, implies that the potential of POS advertisement is wasted.

Price is positive and highly significant, although DiFranza et al. (1994) find that it has a negative but significant relationship with sales decline. Although significant, some firms may be unable to respond to their competitors in a price war. In our case, PMP was found to charge higher prices for medium products than PTC.

We find that quality is insignificant, unlike Randall et al. (1998) who present a positive and significant relationship between quality and sales decline. The difference may be a result of different cultural contexts (interviews conducted in the US versus our survey conducted in Pakistan). Competition is positive and highly significant. Polo et al. (2011) support this result, finding that competition has a positive and significant relationship with sales decline.

Customer preference is negative and insignificant. Cho and Pucik (2005), however, find that it has a significant and negative relationship with sales. We find that product development is positive and highly significant, unlike Reed et al. (2006), who show that it has a negative relationship with 
sales decline. The positive relationship we find may be because of the fear of losing market share and sales due to lack of product development.

Product mix has a positive and highly significant relationship with sales decline. Polo et al. (2011) show a negative relationship between the two variables. The difference in results could be because PMP has a narrow product line and fewer varieties and flavors. The firm's packaging of its medium brands has remained the same but that of its premium brands has changed, thus attracting new customers and retaining old ones.

\section{Conclusion}

This study was conducted to determine which factors affect product sales in the tobacco industry, which is becoming increasingly competitive. Consumers have a very high degree of bargaining power due to the large availability of substitutes. Various factors can affect sales, all of which the company must keep in mind to make its own products more profitable. Customers are conscious of a product's value for money and companies thus have to ensure their product meets consumer preferences.

Pricing is a very important marketing pillar. Our results show that products can gain a considerable market share as a result of pricing. When the price of a particular brand was reduced by half, people perceived it to be superior. In countries such as Pakistan, where purchasing power is in constant decline, products such as cigarettes are very sensitive to changes in price. Brand equity is also related to product performance. Customers reported that they were loyal to those brands that provided more product variety.

Sales are expected to contribute to increased market share and the penetration of new markets as firms gain brand loyalty and customer satisfaction. In the case of PMP, we find that the company has failed to provide variety or to reposition its brands. It has thus been unable to utilize marketing tools as effectively as PTC: brands such as K-2 and Morven are still perceived as being lower-class. Lower prices strongly affect the perception of product quality. People tend to prefer older brands of whose quality they are sure. This indicates that firms should pay more attention to such issues and improve the segment and public image of their products. 


\section{References}

Cho, H.-J., \& Pucik, V. (2005). Relationship between innovativeness, quality, growth, profitability and market value. Strategic Management Journal, 26(6), 555-575.

Danneels, E. (2002). The dynamics of product innovation and firm competences. Strategic Management Journal, 23(12), 1095-1121.

DiFranza, J. R., Eddy, J. J., Brown, L. F., Ryan, J. L., \& Bogojavlensky, A. (1994). Tobacco acquisition and cigarette brand selection among youth. Tobacco Control, 3(4), 334-338.

Donovan, R. J., Jancey, J., \& Jones, S. (2002). Tobacco point of sale advertising increases positive brand user imagery. Tobacco Control, 11(3), 191-194.

Gómez, M., McLaughlin, E., \& Wittink, D. (2004). Customer satisfaction and retail sales performance: An empirical investigation. Journal of Retailing, 80, 265-278.

Honjo, K., \& Kawachi, I. (2000). Effects of market liberalization on smoking in Japan. Tobacco Control, 9(2), 193-200.

Hudmon, K. S., Fenlon, C. M., Corelli, R. L., Prokhorov, A. V., \& Schroeder, S. A. (2006). Tobacco sales in pharmacies: Time to quit. Tobacco Control, 15(1), 35-38.

Katz, S. K., \& Lavack, A. M. (2002). Tobacco-related bar promotions: Insights from tobacco industry documents. Tobacco Control, 11(Suppl. 1), 92-101.

Polo, Y., Sese, F. J., \& Verhoef, P. C. (2011). The effect of pricing and advertising on customer retention in a liberalizing market. Journal of Interactive Marketing, 25(4), 201-214.

Randall, T., Ulrich, K., \& Reibstein, D. (1998). Brand equity and vertical product line extent. Marketing Science, 17(4), 356-379.

Reed, M. B., Anderson, C. M., \& Burns, D. M. (2006). The temporal relationship between advertising and sales of low-tar cigarettes. Tobacco Control, 15(6), 436-441.

Sun, B., Neslin, S. A., \& Srinivasan, K. (2003). Measuring the impact of promotions on brand switching when consumers are forward looking. Journal of Marketing Research, 40(4), 389-405. 


\section{Appendix}

\section{Questionnaire}

1. What is your gender?

- Male

- Female

2. What is your age?

- 18 to 25

- 26 to 33

- 34 to 41

- 42 to 49

- 50 or above

3. What is your salary?

- 15,000 to 25,000

- 26,000 to 36,000

- 37,000 to 47,000

- 48,000 to 58,000

- 59,000 or above

4. Do you think that sales decline affects business?

\begin{tabular}{lllll}
\hline 1 & 2 & 3 & 4 & 5 \\
\hline $\begin{array}{l}\text { Disagree } \\
\text { strongly }\end{array}$ & $\begin{array}{l}\text { Disagree } \\
\text { slightly }\end{array}$ & Neutral & $\begin{array}{l}\text { Agree } \\
\text { slightly }\end{array}$ & $\begin{array}{l}\text { Agree } \\
\text { strongly }\end{array}$ \\
\hline
\end{tabular}

5. Do you think a decrease in sales and brand switching is due to reduced customer loyalty?

\begin{tabular}{|c|c|c|c|c|}
\hline 1 & 2 & 3 & 4 & 5 \\
\hline $\begin{array}{l}\text { Disagree } \\
\text { strongly }\end{array}$ & $\begin{array}{l}\text { Disagree } \\
\text { slightly }\end{array}$ & Neutral & $\begin{array}{l}\text { Agree } \\
\text { slightly }\end{array}$ & $\begin{array}{l}\text { Agree } \\
\text { strongly }\end{array}$ \\
\hline
\end{tabular}

6. Does point-of-sale advertising affect the sale of a product?

\begin{tabular}{lllll}
\hline 1 & 2 & 3 & 4 & 5 \\
\hline $\begin{array}{l}\text { Disagree } \\
\text { strongly }\end{array}$ & Disagree & Neutral & $\begin{array}{l}\text { Agree } \\
\text { slightly }\end{array}$ & $\begin{array}{l}\text { Agree } \\
\text { strongly }\end{array}$ \\
\hline
\end{tabular}

7. Do you think the low pricing of Red \& White, Morven Gold, and K-2 by PMP is an effective strategy?

\begin{tabular}{lllll}
\hline 1 & 2 & 3 & 4 & 5 \\
\hline $\begin{array}{l}\text { Disagree } \\
\text { strongly }\end{array}$ & Disagree & Neutral & $\begin{array}{l}\text { Agree } \\
\text { slightly }\end{array}$ & $\begin{array}{l}\text { Agree } \\
\text { strongly }\end{array}$ \\
\hline
\end{tabular}


8. How satisfied are you with the overall product quality of Red \& White, Morven Gold, and K-2?

\begin{tabular}{lllll}
\hline 1 & 2 & 3 & 4 & 5 \\
\hline $\begin{array}{l}\text { Disagree } \\
\text { strongly }\end{array}$ & $\begin{array}{l}\text { Disagree } \\
\text { slightly }\end{array}$ & Neutral & $\begin{array}{l}\text { Agree } \\
\text { slightly }\end{array}$ & $\begin{array}{l}\text { Agree } \\
\text { strongly }\end{array}$ \\
\hline
\end{tabular}

9. Are customer satisfaction and product quality directly proportional to competition?

\begin{tabular}{lllll}
\hline 1 & 2 & 3 & 4 & 5 \\
\hline $\begin{array}{l}\text { Disagree } \\
\text { strongly }\end{array}$ & Disagree & Neutral & $\begin{array}{l}\text { Agree } \\
\text { slightly }\end{array}$ & $\begin{array}{l}\text { Agree } \\
\text { strongly }\end{array}$ \\
\hline
\end{tabular}

10. Are changing customer preferences and taste directly proportional to sale decline?

\begin{tabular}{lllll}
\hline 1 & 2 & 3 & 4 & 5 \\
\hline $\begin{array}{l}\text { Disagree } \\
\text { strongly }\end{array}$ & Disagree & Neutral & $\begin{array}{l}\text { Agree } \\
\text { slightly }\end{array}$ & $\begin{array}{l}\text { Agree } \\
\text { strongly }\end{array}$ \\
\hline
\end{tabular}

11. Do you think government policies and taxes etc. affect sales?

\begin{tabular}{lllll}
\hline 1 & 2 & 3 & 4 & 5 \\
\hline $\begin{array}{l}\text { Disagree } \\
\text { strongly }\end{array}$ & Disagree & Neutral & $\begin{array}{l}\text { Agree } \\
\text { slightly }\end{array}$ & $\begin{array}{l}\text { Agree } \\
\text { strongly }\end{array}$ \\
\hline
\end{tabular}

12. Are you satisfied with the PMP product with respect to packing, label, and size (product mix)?

\begin{tabular}{lllll}
\hline 1 & 2 & 3 & 4 & 5 \\
\hline $\begin{array}{l}\text { Disagree } \\
\text { strongly }\end{array}$ & $\begin{array}{l}\text { Disagree } \\
\text { slightly }\end{array}$ & Neutral & $\begin{array}{l}\text { Agree } \\
\text { slightly }\end{array}$ & $\begin{array}{l}\text { Agree } \\
\text { strongly }\end{array}$ \\
\hline
\end{tabular}

13. Do you think that diversification or market development leads to increased sales and profits?

\begin{tabular}{lllll}
\hline 1 & 2 & 3 & 4 & 5 \\
\hline $\begin{array}{l}\text { Disagree } \\
\text { strongly }\end{array}$ & Disagree & Neutral & $\begin{array}{l}\text { Agree } \\
\text { slightly }\end{array}$ & $\begin{array}{l}\text { Agree } \\
\text { strongly }\end{array}$ \\
\hline
\end{tabular}

14. Do you think that social marketing helps increase product sales?

\begin{tabular}{lllll}
\hline 1 & 2 & 3 & 4 & 5 \\
\hline $\begin{array}{l}\text { Disagree } \\
\text { strongly }\end{array}$ & Disagree & Neutral & $\begin{array}{l}\text { Agree } \\
\text { slightly }\end{array}$ & $\begin{array}{l}\text { Agree } \\
\text { strongly }\end{array}$ \\
\hline
\end{tabular}


15. Do you think PMP should introduce new flavors and low-tar cigarettes (product mix)?

\begin{tabular}{lllll}
\hline 1 & 2 & 3 & 4 & 5 \\
\hline $\begin{array}{l}\text { Disagree } \\
\text { strongly }\end{array}$ & $\begin{array}{l}\text { Disagree } \\
\text { slightly }\end{array}$ & Neutral & $\begin{array}{l}\text { Agree } \\
\text { slightly }\end{array}$ & $\begin{array}{l}\text { Agree } \\
\text { strongly }\end{array}$ \\
\hline
\end{tabular}

16. How satisfied are you with PMP's sales promotions for its products?

\begin{tabular}{lllll}
\hline 1 & 2 & 3 & 4 & 5 \\
\hline $\begin{array}{l}\text { Disagree } \\
\text { strongly }\end{array}$ & Disagree & Neutral & $\begin{array}{l}\text { Agree } \\
\text { slightly }\end{array}$ & $\begin{array}{l}\text { Agree } \\
\text { strongly }\end{array}$ \\
\hline
\end{tabular}

Source: Based on D. J. Faulds, W. G. Mangold, \& P. S. Raju. (2009). Big Red, Ltd. Journal of Business Case Studies, 5(5), 29-54. 